\title{
The Pliska Inscription
}

\author{
Giancarlo T. Tomezzoli ${ }^{1}$, Rainhardt S. Stein ${ }^{2}$ \\ ${ }^{1}$ Etno-Archaeological Observatory, Munich, Germany \\ ${ }^{2}$ Universiteit Utrecht, Utrecht, Holland \\ Email: gt21949@gmx.de,rstein@uu.nl
}

How to cite this paper: Tomezzoli, G. T. \& Stein, R. S. (2020). The Pliska Inscription. Archaeological Discovery, 8, 84-91. https://doi.org/10.4236/ad.2020.81005

Received: October 23, 2019

Accepted: November 18, 2019

Published: November 21, 2019

Copyright $\odot 2020$ by author(s) and Scientific Research Publishing Inc. This work is licensed under the Creative Commons Attribution International License (CC BY 4.0).

http://creativecommons.org/licenses/by/4.0/

\begin{abstract}
In this article, the strong resemblance of Linear A, Linear B characters with the Proto-Bulgarian characters of the Pliska inscription is used for identifying the phonetic value of each Proto-Bulgarian character. Because said characters are on rays of a rosette, several inscription readings are possible. The selection of the valid reading, its separation in words and its deciphering were made on the basis of similarities between the inscription words and corresponding words in the surviving Slavic languages. The resulting deciphering is: the massacre of the Romans drink glum, but resist at, which can be loosely deciphered as: drink the bitter cup of the Roman massacre glum, but hold on together. The massacre mentioned in the inscription was certainly that that occurred during the war between the Bulgarians of khan Krum and the Byzantines of emperor Nikephoros, when this last on $20^{\text {th }}$ July 811 sieged Pliska, capital of the First Bulgarian Empire, plundered its treasures and burned it to ground.
\end{abstract}

\section{Keywords}

Pliska, Rosette, Inscription, Proto-Bulgarian, Linear A, Linear B

\section{Introduction}

The rosette, on which the inscription is engraved, is numbered 38 in the Catalogue of archaeological finds from Pliska (Henning, 2007) and is laconically described as: Rosette; Large water storage; $9^{\text {th }}$ cen.; Bronze; cast; Engraving. Around a raised round center part there are grouped seven trapezoidal rays. On one side at the center part the engraved character IYI. On the other side, a hanger loop. Two characters on each ray blade. Diam.: 3.9 cm. Nat. Arch. Mus. Sofia, Inv. 5257.

\section{The Inscription Studies}

The rosette attracted the attention of the experts because of its beautiful seven 
rays shape and its obscure meaning.

An inscription deciphering attempt was based on Semitic scripts, the ancient Turk and Chuvasian languages. The character group IYI was interpreted as "yuvi" i.e. them, a title brought only by the khan. The deducted inscription meaning was: this for horse riding should be known, carries the seal at home. The inscription and the rosette shape indicated then the rosette as a connection of chest straps in horse equipment (Sachev, 1977).

A Proto-Bulgarian (P-Blg.) character comparative analysis confirmed the characters as forming a P-Blg. inscription and revealed analogies between its P-Blg. characters and other characters engraved on artefacts found in nearby regions of today Bulgaria. Some reading issues were raised:

1) In which sequence the rays should be considered?

2) Which is the first character in each ray: the internal one or the external?

3) How the characters should be seen, as they appear or overturned?

4) If the characters should be read in circular mode, should be read first the characters on the external circumference or those of the internal circumference?

5) How the characters should be read, by rotating the rosette leftward or rightwards?

The inscription meaning was not determined; however, the rosette was considered either a warrior emblem or part of horse equipment, destined to be attached to a perishable material. In use, only the character group IYI was visible to other peoples, while the inscription on the hanger loop side (Figure 1) was not visible. The inscription was then considered either a pray, or an oath, or a war call (Vaklinov, 1978).

A study conjectured the character group IYI, found also on many stones and artefacts in Bulgaria, having seven endpoints as the number of the rosette rays, to represent the heaven or sky and the characters on the rays to represent the Sun, Moon, Mars, Mercury, Jupiter, Venus and Saturn. The rosette was then considered a divination tool. It had to be put in rotation on the hanger loop and, at the end of the rotation, the characters of the ray on which it remained supported indicated what was to be done that day and whether it have to be successful or not (Beshevliev, 1981).

Another study was based on similarities between the P-Blg. inscription words and corresponding Elam, Acadian, Sumer, Assyrian-Babylonian words. IYI was assumed to indicate the Sun and according to the above conjecture, the characters on the rays were assumed to indicate the Moon, Mars, Mercury, Jupiter, Venus and Saturn. The union of the characters gave the reading YOHOHKXE ШAP САНЬЭХЭ which referred to khan Vonont and its title (Dobrev, 1992; Dobrev, 1994).

Other studies assumed that the characters were rune-like characters (Mihailov, 1995; Ovcharov, 1995).

A further study raised the issue of inconsistencies in different publications, concerning wrong orientations of the hanger loop and of the ray characters. IYI 
was assumed to be a religious symbol indicating the Sun. The characters on the rays indicated the Sun and the positive gods Venus, Moon, Jupiter and the negative gods Mars, Saturn and Mercury. The correct inscription reading was indicated to be from left to right (Ivanov, 2019).

An attempt to date the rosette, assumed that it was a divination tool. The correspondence characters/zodiacal constellations found was: 1 Sagittarius, 3 Aries, 5 Pisces, 7 Taurus, 9 Scorpius, 11 Virgo, 13 Aquarius and the correspondence characters/planets found was: 2 Mars (red horse), 4 Moon, 6 Sun, 8 Venus, 10 Saturn, 12 Jupiter, 14 Mercury (black horse) (Figure 1). The consequent celestial configuration was: Sun in Pisces, Mercury in Aquarius, Venus in Taurus, Mars in Sagittarius, Jupiter in Virgo and Saturn in Scorpius corresponding to the time interval $29^{\text {th }}$ March 1104-13 ${ }^{\text {th }}$ April 1104 AD or, in relaxed conditions, $10^{\text {th }}$ April $867-15^{\text {th }}$ May $867 \mathrm{AD}$ and three other intervals (Sidorov, 1997; Sidorov \& Kelevedzhiev, 2000).

\section{The Inscription Reading}

The above studies are all very interesting, but no one considered the surprising correspondence between the P-Blg. inscription characters and Linear A (LA), Linear B (LB) characters (Serafimov, 2008). Figure 1 shows the side of the rosette hosting the hanger loop and the inscription.

In the light of the issues 1), 3) (Vaklinov, 1978), we assumed that:

- The reading starting point is the ray approximately indicated by a straight line crossing the hole in the hanger loop (Figure 1). The possible starting point indicated by the upper portion of the character $\mathrm{Y}$ of the character IYI, adopted in some of said studies, appears not convincing because said upper portion is located on the rosette side opposed to the inscription side and thus invisible for a reader of the inscription.

- The P-Blg. characters should be seen as the corresponding LA, LB characters are normally seen.

The correspondence between the P-Blg. characters and LA, LB characters has been identified by means of LA, LB grids (Younger, 2017) (Table 1). The fact that each one of the $14 \mathrm{P}-\mathrm{Blg}$. characters finds a unique and sure corresponding LA or LB character in said grids confirms that a link existed between the P-Blg. writing and the LA, LB writings.

Because the phonetic value of each corresponding LA, LB character in said grids is known and assuming that each P-Blg. character preserved the same or a similar phonetic value of the corresponding LA, LB character, the phonetic value of each P-Blg. character has been determined (Table 1).

In the light of the issues 2), 4), 5) (Vaklinov, 1978), we assumed the following possible reading modes:

1) Clockwise, from the exterior to the interior:

re pi sa a ro no mi di mpu ra pe ti su pi $(1,2,3,4,5,6,7,8,9,10,11,12,13$, 14). 


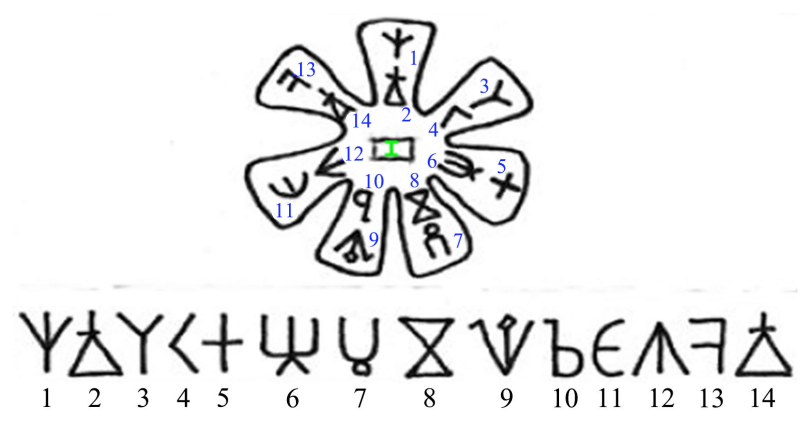

Figure 1. Pliska rosette-P-Blg. inscription characters on the hanger loop side; hanger loop at the centre of the rosette; hanger loop hole indicated in green; IYI character group invisible because on the rosette opposite side; P-Blg. inscription characters; character numbering.

Table 1. Phonetic value identification: P-Blg. Ch $\mathrm{N}=\mathrm{P}-\mathrm{Blg}$. character numbering; $\mathrm{Ph}$. Value $=$ Phonetic Value; AB 1-92 = AB 1-92 grid identified LB characters, Lin. A Syl. = LA Syllabary grid identified LA characters, Lyn. B Syl. = Conventional LB Syllabary grid identified LB characters, Mel. Syl. = Melena's Full LB Syllabary grid identified LB characters.

\begin{tabular}{|c|c|c|c|c|c|}
\hline P-Blg. Ch N & Ph. Value & $\mathrm{AB} 1-92$ & Lin.A Syl. & Lin. B Syl & Mel. Syl. \\
\hline 1 & re & col. $7, \ln 2$ & RE 27?? & RE 27 & $\mathrm{re}^{\star} 27$ \\
\hline 2 & pi & col. $9, \ln 3$ & PI 39 & PI 39 & $\mathrm{pi}^{\star} 39$ \\
\hline 3 & sa & col. $1, \ln 3$ & SA 31?? & & $\mathrm{sa}^{*} 31$ \\
\hline 4 & a & col. $4, \ln 3$ & & *34 unk. & $\mathrm{a}_{5}^{? ? * 34 / \mathrm{ai} /}$ \\
\hline 5 & ro & col. $2, \ln 0$ & $\mathrm{RO} 2$ & RO 2 & ro ${ }^{\star} 02$ \\
\hline 6 & no & col. $2, \ln 5$ & & NO 52 & no $* 52$ \\
\hline 7 & $\mathrm{mi}$ & col. $3, \ln 7$ & & MI 73 & \\
\hline 8 & di & & $318 \mathrm{DI}_{2} ? ?$ & & \\
\hline 9 & $\mathrm{mpu}$ & & ${ }^{m} \mathrm{PU}_{2} 29 ? ?$ & & \\
\hline 10 & ra & & RA 60 & & $\mathrm{ra}^{\star} 60$ \\
\hline 11 & pe & col. $7, \ln 2$ & & PE 72 & $\mathrm{pe}^{\star} 72$ \\
\hline 12 & $\mathrm{ti}$ & col. $7, \ln 3$ & & TI 37 & $\mathrm{ti}^{\star} 37$ \\
\hline 13 & su & col. $8, \ln 5$ & SU 58 & SU 58 & $\mathrm{su}^{\star} 58$ \\
\hline 14 & pi & col. $9, \ln 3$ & PI 39 & PI 39 & $\mathrm{pi}^{\star} 39$ \\
\hline
\end{tabular}

2) Counter clockwise, from the exterior to the interior:

re pi su pi pe ti mpu ra mi di ro no sa a $(1,2,13,14,11,12,9,10,7,8,5,6,3$, 4).

3) Clockwise, from the interior to the exterior:

pi re a sa no ro di mi ra mpu ti pe pi su $(2,1,4,3,6,5,8,7,10,9,12,11,14$, 13).

4) Counter clockwise, from the interior to the exterior:

pi re pi su ti pe ra mpu di mi no ro a sa $(2,1,14,13,12,11,10,9,8,7,6,5,4$, 3). 
5) Clockwise, zigzag:

re pi a sa ro no di mi mpu ra ti pe pi su $(1,2,4,3,5,6,8,7,9,10,12,11,13$, 14).

6) Counter clockwise, zigzag:

re pi pi su pe ti ra mpu mi di no ro sa a $(1,2,14,13,11,12,10,9,7,8,6,5,3$, 4).

7) Clockwise, inverted zigzag:

pi re sa a no ro mi di ra mpu pe ti pi su $(2,1,3,4,6,5,7,8,10,9,11,12,14$, 13).

8) Counter clockwise, inverted zigzag:

pi re pi su ti pe mpu ra di mi ro no a sa $(2,1,13,14,12,11,9,10,8,7,5,6,4$, $3)$.

9) Clockwise, ext. circumf. + int. circumf.:

re sa ro mi mpu pe su pi a no di ra ti pi $(1,3,5,7,9,11,13,2,4,6,8,10,12$, 14).

10) Counter clockwise, ext. circumf. + int. circumf.:

re su pe mpu mi ro sa pi pi ti ra di no a $(1,13,11,9,7,5,3,2,14,12,10,8,6$, 4).

11) Clockwise, int. circumf. + ext. circumf.

pi a no di ra ti pi re sa ro mi mpu pe su $(2,4,6,8,10,12,14,1,3,5,7,9,11$, 13).

12) Counter clockwise, int. circumf + ext. circumf.:

pi pi ti ra di no a re su pe mpu mi ro sa $(2,14,12,10,8,6,4,1,13,11,9,7,5$, $3)$.

\section{The Inscription Deciphering}

The reading mode 9), containing the character groups resa, romi, supi, dirati, pi having clear substantival and verbal similarities in the today surviving Slavic languages, attracted immediately our attention. Said groups helped to subdivide the inscription in words as follows:

resa romi mpupe supi a no dirati pi

and to decipher the words as follows:

resa: massacre, Bel.: разня, Rus.: резня, Ukr.: різанина;

romi: Romans, Bel. рымляні, Blg. римски, Pol. rzymski, Rus.: римляни, Ser.: римски, Ukr.: римляни;

mpupe: drink, Bel. піць, Mac. Blg. питие, Mac. пијат, Russ.: питьё, Ser.: пиће, Slo. pijača, Slv. pitie, Ukr.: питво;

supi: glum, Bel. супити, Rus. супити, Ser. супити, Ukr. супить,

a no: but, Blg.: Ho, Mac.: Ho, Rus.: a, Hо;

dirati: to resist, to maintain, Blg. да държа, Cro. držati/drži se, Rus. держать/ держатся, Ser. держать/држи се, Slo. držati/drži se, Slv. držat;

pi: in, at, Вlg.: при, Russ. При.

Wherein: Bel. Belarussian, Blg. Bulgarian, Mac. Macedonian, Pol. Polish, Rus. 
Russian, Ukr. Ukrainian, Cro. Croatian, Ser. Serbian, Slo. Slovenian, Slv. Slovakian.

Consequently, the complete inscription deciphering is:

the massacre of the Romans drink glum, but resist at.

Or in loose deciphering:

drink the bitter cup of the Roman massacre glum, but hold on together.

The deciphered words permit to appreciate the archaism of the P-Blg. with respect to the present surviving Slavic languages. The other reading modes do not appears to contain character groups suitable for deciphering.

\section{Discussion}

At first glance, the strong similarity between LA, LB and P-Blg. characters appears rather strange. In fact, according to the current vision, either LB was created on the Greek Mainland and brought to Crete during the Mycenaean conquest or was adapted from LA on Crete and then brought to the Greek Mainland (Thebe, Mycenae, Miletus), both, however, for use in palace economies in administrative communications. The collapse of the Mycenaean centres (1300-1100 BC) led to the disappearance of LB documents both literary and administrative (Melena, 2014).

However, the similarity of the LA, LB and the inscription writings suggests that LA, LB were known not only in the Aegean Islands and the Greek Mainland but in general also in the Balkans and the Black Sea coasts, and the knowledge survived the influences of Greeks, Romans and Byzantines.

The settlement of the Aegean Islands, the Balkans and Black Sea coasts is complex and not well known. Recently, some authors (Serafimov \& Tomezzoli, 2011; Serafimov \& Tomezzoli, 2012; Tomezzoli \& Serafimov, 2013) challenged the current VI cen. AD theory of the late Slavs arrival in East Europe and highlighted the more ancient Slavs East Europe presence. Therefore, also Slavic populations became aware of the LA, LB characters and evidently adopted them for their languages.

Apparently, there is no attested continuation between LA, LB $\left(18^{\text {th }}-12^{\text {th }}\right.$ cen. $\mathrm{BC})$ and P-Blg. $\left(4^{\text {th }}-8^{\text {th }}\right.$ cen. $\left.\mathrm{AD}\right)$. In the long period $11^{\text {th }}$ cen. $\mathrm{BC}-4^{\text {th }}$ cen. $\mathrm{AD}$ there is, at least until now, no attested written documents in LA, LB and P-Blg. This absence can be easily explained by observing that said documents were normally current documents not intended for lasting a long time, perhaps, few days, few weeks, some months or some year (Serafimov, 2008). Therefore, perishable support materials like unbacked clay, wood, wood bark and animal hides were largely used by the Mycenaeans and ancient Balkans and the Black Sea Slavs for writing their current documents. Due to the perishable materials limited duration no such document survived. Rarely and in case of relevant information, were the documents written on non-perishable materials like stones and metal objects (Serafimov, 2008).

Note also that it was only by chance, i.e. because of unintentional expositions of their unbaked clay tablets to flames which fire-hardened them and because 
the inscription was engraved in the rosette bronze which preserved it, that the strong similarity between LA, LB and P-Blg. characters has been revealed.

It could also be possible that LA, LB, Glagolitic and P-Blg. and may be LA, LB characters developed from the much older Vinca characters (Serafimov, 2008). It is also noted that the oldest appearance of the character group IYI is in the $5^{\text {th }}$ millennium BC on Vinca culture potteries (Михайлов, 1987).

The rosette was probably part of a fibula destined, by means of a pin or a brooch to close a mantel, letting in vision the IYI character group on one side but masking the inscription on the side of the hanger loop.

The Romans, mentioned in the inscription, were surely the Byzantines and the massacre, mentioned in the inscription, certainly occurred during the war between the Bulgarians of prince Krum (796/803-814 AD) and the Byzantines of emperor Nikephoros I (802-811 AD), when this last on $20^{\text {th }}$ July 811 sieged Pliska, capital of the First Bulgarian Empire, plundered its treasures and burned it to ground (Wikipedia, 2019). The rosette and the inscription mentioning the massacre would therefore be manufactured after July 811 AD. The inscription asking peoples to resist Byzantines confirms the hypothesis (Vaklinov, 1978) that it was a war call.

\section{Conclusion}

In our opinion, the relatively easy deciphering and the adherence of the inscription message with a real historical event support also the a posteriori hypothesis that a link existed between LA, LB and P-Blg. writings. A further confirmation could arrive from a rosette datation based on radiometric dating methods.

\section{Conflicts of Interest}

The authors declare no conflicts of interest regarding the publication of this paper.

\section{References}

Beshevliev, V. (1981). Prabylgarski epigrafski pametnici (p. 23). Sofia. (In Bulgarian)

Dobrev, P. (1992). Kamennata kniga na prabylgarite (pp. 91-95). Sofia. (In Bulgarian)

Dobrev, P. (1994). Svetyt na prabylgarite (pp. 104-105). Sofia. (In Bulgarian)

Henning, J. (2007). Catalogue of Archaeological Finds from Pliska. In Millennium Studies in the Culture and History of the First Millennium C.E. Post-Roman Towns, Trade and Settlement in Europe and Byzantium (Vol. 2). Berlin, New York: Walter de Gruyter. https://books.google.de/books?id=3oCI8BVxcB8C\&pg=PA671\&lpg=PA671\&dq=Teofil ov+2000;+Ra\%C5\%A1ev+2003,+165+pliska+rosette\&source=bl\&ots=MBBO5SBy8v\&s ig=ACfU3U0M4DTTGLe7OkW2Wussr-sCESIDiw\&hl=en\&sa=X\&ved=2ahUKEwidqI TrktPkAhXD2aQKHU0yBXUQ6AEwCnoECAgQAQ\#v=onepage\&q=Teofilov\%20200 0\%3B\%20Ra\%C5\%A1ev\%202003\%2C\%20165\%20pliska\%20rosette\&f=false https://doi.org/10.1515/9783110218831.3.661

Ivanov, I. T. (2019). Космологични представи на древните българи съгласно бронзовата Розета от Плиска. 
http://сувары.pф/ru/content/kosmologichni-predstavi-na-drevnite-blgari-sglasno-bro nzovata-rozeta-ot-pliska

Melena, J. L. (2014). Mycenaean Writing. A Companion to Linear B. Mycenaean Greek Textes and Their World. In D. Dououx, \& M. Davies (Ed.), Bibliothèque des Cahiers de I'Institut de Linguistique de Louvain (Vol. 3). Peeters: Louvain-la-Neuve.

Михайлов, С. (1987). Към тълкуването на сложния знак IYI и на израза Медното Гумно, Известия на Народния Музей във Варна 23 (28). Книгоиздателство “Георги Бакалов”. Варна. (In Bulgarian)

Mihajlov, S. (1995). Kym tylkuvaneto na bronzovata sedmolychna rozeta ot Pliska. Starobylgaristika, No. 2, 94-101. (In Bulgarian)

Ovcharov, D. (1995). Otnovo za bronzovata sedmolychna rozeta ot Pliska. Starobylgaristika, No. 4, 114-115. (In Bulgarian)

Sachev, E. (1977). Nadpisyt vyrhu bronzovata rozeta ot Pliska. Vekove, No. 6, 78-81. (In Bulgarian)

Serafimov, P. (2008). The Origin of the Glagolithic Alphabet. In Proceedings of the Sixth International Topical Conference on Origin of Europeans (pp. 99-117). Ljubljana. http://www.korenine.si/zborniki/zbornik08/glagolitic.pdf

Serafimov, P., \& Tomezzoli, G. (2011). Evidence of Early Slavic Presence in Minoan Crete. In Proceedings of the Ninth International Topical Conference on Origin of Europeans (p. 219). Ljubljana.

Serafimov, P., \& Tomezzoli, G. (2012). New Reading of the Linear a Inscription on the Golden Pin CR-ZF-1 from Crete. In Proceedings of the Tenth International Topical Conference on Origin of Europeans (p. 83). Ljubljana.

Sidorov, M. (1997). Blygarianstvoto-religijata na Sedemte (pp. 97-104). Sofia. (In Bulgarian)

Sidorov, M., \& Kelevedzhiev, E. (2000). An Approach to Dating the Pliska Rosette. Institute of Mathematics and Informatics at Bulgarian Academy of Sciences. Sofia. http://www.math.bas.bg/ keleved/dplisros

Tomezzoli, G., \& Serafimov, P. (2013). The Linear A Inscriptions II.1, II.2 from the Palace of Knossos. In Proceedings of the Eleventh International Topical Conference on Origin of Europeans (p. 105). Ljubljana.

Vaklinov, S. (1978). Ein Denkmal Runischen Schrifttums Pliskas. In Studia in honorem veselin besevliev (pp. 245-254). Sofia.

Wikipedia (2019). https://en.wikipedia.org/wiki/Krum

Younger, J. (2017). Linear A \& Linear B Grids.

http://www.people.ku.edu/ jyounger/LinearA/ABgrids.html 